Article

\title{
Iron Age Cultic Sites in Transjordan
}

\author{
Margreet L. Steiner
}

Independent Scholar, 2300 Leiden, The Netherlands; msteiner@freeler.nl

Received: 29 January 2019; Accepted: 20 February 2019; Published: 27 February 2019

\begin{abstract}
In the area east of the river Jordan, eight Iron Age structures identified as cultic have been excavated. This paper presents the evidence as published and discusses the relevance of the cultic identification of the structures.
\end{abstract}

Keywords: cult sites; Transjordan; Iron Age; Deir Alla; Pella; Damiyah; Ataruz; Mudayna Thamad; WT-200; Busayrah

\section{Identification of Cultic Places}

Cult places such as temples, shrines, or open-air cultic complexes are an important part of the 'religious landscape' of ancient peoples. However, the identification of excavated buildings as cult places is not unambiguous. Much research has gone into the question of how cult practices and ritual behaviour express themselves in the material culture and how to follow the trail, so to speak, from cult to excavated remains (see for instance Blake 2005). The problem many field archaeologists are struggling with is rather how to interpret archaeological remains and which criteria to apply in order to define these remains as related to cultic practices. This may be the same trail, but walking it backwards. Not: which traces do cult practices leave in the archaeological record, but: which archaeological remains may be connected to cultic practices. To establish this is a much harder endeavour. Two examples are below.

Rituals concerning the communal consumption of meat may leave traces in the ground in the form of hundreds of animal bones. But not every find of large amounts of animal bones should be interpreted as evidence of those rituals and thus of the cultic nature of the site in question. Other explanations are possible, such as butchering for household consumption, the communal consumption of meat not connected with a religious ritual but, for instance, a wedding, or it being the remains of a dump site.

The placing of figurines as votive objects in a shrine often results in the excavations of many such objects in a building, but not every building containing figurines is by definition a shrine. Figurines may have been used and are often found in domestic contexts and tombs. The building may be the place where such objects were made, stored or sold, or maybe figurines were used not only as votive objects. Arguing from cult practices (the placing of votives in a shrine) to archaeological finds (the presence of figurines in a building) is much more straightforward than arguing from the excavated remains (figurines in a building) to cult practices (so this building is a shrine). As the 'backward trail' is hard to follow, archaeologists have to use the criteria that argue from cult practice to material culture, bearing in mind that other explanations are possible and should be examined.

\section{Criteria}

Various criteria have been used to identify buildings and objects as religious or cultic in nature. Coogan (1987) formulated four such criteria: isolation as a result of the separation of the sacred from the profane, the presence of exotic materials, continuity of religious buildings on multi-period sites and parallels of architectural features. 
In his report on the site of Phylakopi, Renfrew (1985) established 18 criteria. The list has been repeatedly modified and adjusted, recently by Zevit (2001, p. 82) who adapted it "to reflect the possibilities of the Iron Age sites in Syria-Palestine" and by Daviau (2012) who concentrated on the rituals taking place at cultic sites.

These criteria argue from ritual to material remains, not the other way around. Zevit's first two criteria, for instance, postulate that "Rituals may be performed in a place of natural significance, such as a cave, spring, mountain top, or a groove of trees" and that "They may be performed in a place of historical significance, e.g., the site of a theophany to an ancestor, or a famous event, or a grave". It is easier to argue that a ritual may have taken place in a cave than to interpret the remains in a certain cave as cultic.

Moreover, most criteria are 'fluid'. How many criteria have to apply? Do they have to apply completely or partly? How many special pottery types have to be present to define a site as cultic? How great the investment of wealth? How tight the parallels? The danger of circular argumentation is lurking. The presence of 'cultic vessels', for instance, strengthens the interpretation of a site as cultic, but the vessels are deemed 'cultic' in the first place because they are often found not in domestic contexts but in what is interpreted as temples or shrines.

Some indicators are more convincing than others. The presence of animal bones can be an indicator for offering practices, but need not be, as argued above. Food such as fruits may have been consumed in a ritual, but may also have constituted the daily evening meal. So these are weak indicators. Statues and inscriptions, on the other hand, are strong ones. The more indicators are present and the stronger they are, the more certain the identification as cultic.

So, whereas in Mesopotamia and the northern Levant the identification of a site or building as cultic is mostly secure and generally accepted because of the overwhelming evidence in the form of specially designed buildings, inscriptions, large statues, continuity over centuries and the presence of exotic materials, as for instance in the temples at Aleppo and Ain Dara in Syria (Kohlmeyer 2012; Novak 2012), in the southern Levant, the interpretation is often uncertain and per force based on insufficient data.

\section{Iron Age Cultic Sites Excavated in Transjordan}

In the area east of the river Jordan, eight possible Iron Age cult places (temples or shrines) have been excavated: three in the Jordan Valley (part of ancient Ammon), four in Moab, and one in Edom (Figure 1). ${ }^{1}$ These buildings have been identified as cultic by their excavators, followed sometimes by much scholarly discussion. This paper will present the evidence as published so far and discuss the identifications, using the criteria of Zevit and Daviau outlined above (Figure 1).

1 A complex interpreted as an Iron Age moon temple has recently been discovered at Rujm al-Kursi near Amman (see also the article by Tyson in this volume). A large building featured two stone reliefs at the entrance made of hewn white limestone blocks, each depicting a moon sickle on a pedestal. However, only the outlines of the building have been traced (it has not been excavated), and no Iron Age pottery from it has been published so far. Thus, both the dating and the plan of the complex remain uncertain, and in my view an interpretation as an Iron Age temple is premature. See further (Hübner 2009; Elkowicz 2014; and Tyson 2014, pp. 38-39). 


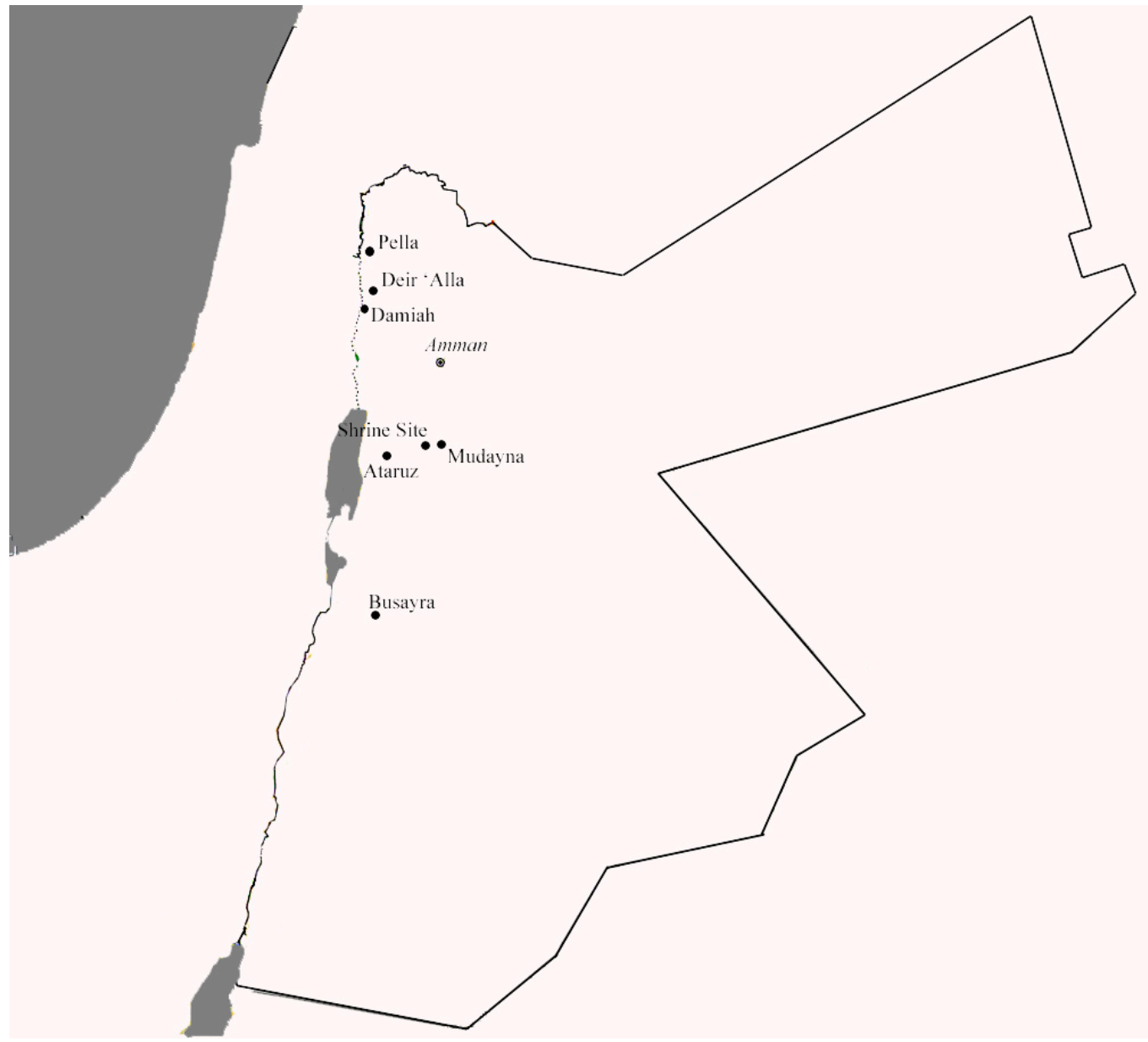

Figure 1. Map of sites mentioned in the text.

\subsection{Deir Alla}

In the Jordan Valley, the most renowned cult place is at Tell Deir Alla. In 1967, a large text, painted on the plaster of a wall, was found in a small building. The text refers to the seer Balaam, son of Beor, known from the Bible (Numbers 21-24). The plaster was found in two heaps east and west of the wall on which the text was supposedly written, thrown there when an earthquake struck the village around 800 BC (Hoftijzer and van der Kooij 1976, 1991).

The text is clearly religious in nature and the room it belonged to $(\mathrm{E} 335,3 \times 4.3 \mathrm{~m})$ had benches on four sides. Benches in a building are often seen as a sign of its cultic nature. The benched room is part of a complex of rooms and courtyards in Phase IX. All in all, some forty rooms have been excavated in this unwalled village, forming 14 to 15 households. Ordinary household wares, bread ovens, storage facilities, and loom weights were found in every household. The benched room yielded no exotic or cultic materials, but some interesting finds were made in a nearby complex.

North of the benched room was an open courtyard with three bread ovens. From this courtyard one entered a complex of three rooms in which 18 loom weights were excavated. Boertien (2008) connects this weaving complex with the benched room and suggests that textiles were woven here for the goddess Shagar, the main goddess mentioned in the Balaam text. This interpretation is based on the special kind of textile made of hemp that was woven at Deir Alla and on a parallel with Kuntillet Ajrud, where another kind of rare textile was found in connection with a shrine.

Near the entrance of the weaving complex north of the benched room, an inscribed stone was found as well as a goblet and a very large loom weight, which all may have had cultic functions. The stone was inscribed with the words eben shar'a ("stone of shar'a"). Franken (2008, p. 44) connects the 
name 'shar'a' with the river Zerqa that runs close by the tell. The same words were incised on a jug found in another room of this complex.

Interpretations of the benched room vary from a Balaam height or cultic cave where people could come into contact with the gods while dreaming (Franken 2008) to a shrine for the goddess Shagar (Boertien 2008), with outlyers such as a classroom for the teaching of scribes (Van der Kooij 2002, p. 69) and "a meeting place of a group of prophets ... were the visions and deeds of that Balaam were remembered" (Wenning and Zenger 1991, p. 198).

Although the benched room and the building complex it belonged to did not yield many exotic or cultic materials, the benches, the special fabrics woven at the site, the inscribed stone and libation goblet and the outsize loom weight found in adjacent rooms as well as the content of the Balaam text undeniably point to the cultic nature of the building. There is no continuity with the Late Bronze Age temple excavated at the site which was located more to the west of the tell. The parallel with the shrine at Kuntillet Ajrud has been mentioned above. Zevit (2001, p. 250, n. 201) concludes that the Balaam inscription justifies the interpretation of the building as a shrine. Which rituals were performed in the shrine at Deir Alla remains unclear.

\subsection{Pella}

Some $30 \mathrm{~km}$ north of Deir Alla and on the edge of the highlands lies Pella, a large site consisting of two tells and a Roman/Byzantine city located between the tells. In recent years, a temple complex has been excavated here, with six superimposed temples, the earliest one from the Middle Bronze Age I, ca. 1900 BC (Bourke 2004, 2012).

The uppermost temple was built ca. 950 BC. It is much smaller (ca. $12 \times 8 \mathrm{~m}$ ) than its Bronze Age predecessors and built in a 'bent-axis' design (Figure 2). It consists of a central room with benches around its north and west sides and what appears to be a stepped podium for the display of votive objects. This room was found empty except for several red-slipped plates. The smaller northern room was filled with baskets of lentils and bags of grain burnt in the final destruction which took place around $800 \mathrm{BC}$. This destruction may be the result of the same earthquake that destroyed Deir Alla, although the excavator does not exclude "a human agency in the destruction" (Bourke 2012, p. 191).

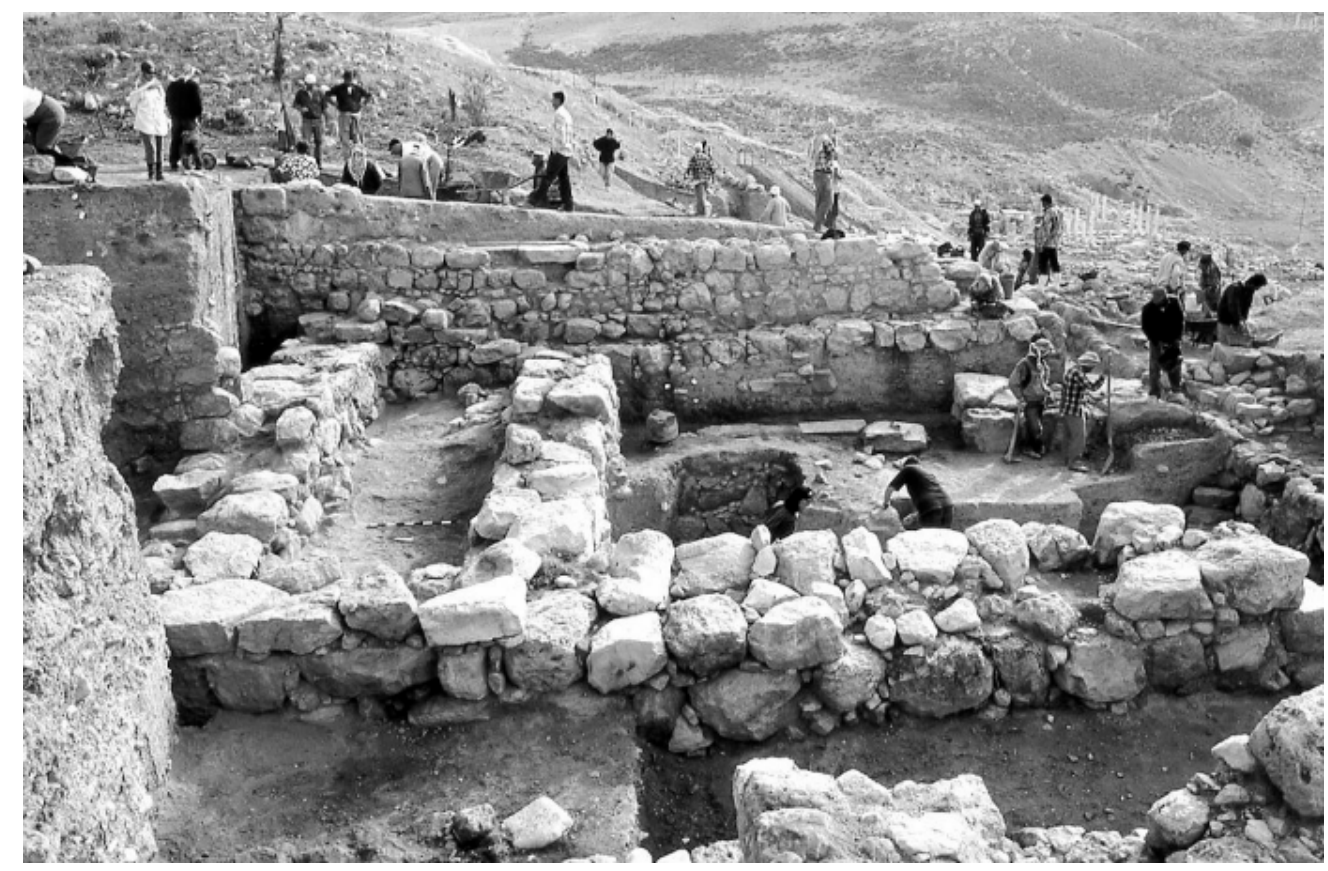

Figure 2. The uppermost temple at Pella (Courtesy Stephen Bourke). 
To the east of the room is an open courtyard with several pits and a stone-built altar. Many objects were recovered from these 'votive offering pits' and from the destruction debris besides the altar. These include ring kernoi, petal-garlanded chalices, fragments from several square stands, a model shrine with bulls-head protomes, incense cups and fragments of at least one large cauldron with ceramic bulls-head protomes. Not many figurines were found, but these include a fragment of an Ashdoda figurine and a male head wearing a polos headgear.

A variety of basalt and limestone vessels, braziers, and scoops were among the non-ceramic finds. Household vessels were abundant, such as large storage jars, cooking pots and bowls. According to the excavator, this may indicate a less strict division between sacred and profane than in the earlier temples or a remarkable change in offering rituals (Bourke 2012, p. 190). Burnt offering seems to have taken place in the courtyard, as many pits contained animal bones, mostly of young sheep and goat.

This building can be identified confidently as cultic because of the continuity with the earlier Bronze Age temples, the presence of special pottery vessels such as the kernoi, chalices and model shrines, and the altar and favissae in the courtyard. To which deity the temple was dedicated remains a mystery, however. Bourke (2012, p. 191) tentatively connects this temple with a change in religious beliefs and practices, possibly connected with the arrival of Aegean-type people in the Jordan valley. His arguments are based on parallels with the Iron Age II Level X temple at Tell el-Qasile and the finds of the incomplete Ashdoda figurine and the scoops, as these objects are supposed to have an Aegean origin.

\subsection{Damiyah}

Southeast of Deir Alla and close to the Jordan lies the small tell of Damiyah, near a ford in the river. Excavations in 2014 and 2015 have unearthed a $14 \times 6$ m mudbrick building with one or two platforms. Its walls were covered by white wash or lime plaster. This partially excavated building and the street south of it so far yielded eight complete unbroken terracotta horse figurines (Figure 3) and four female figurines as well as a pottery stand, two headless terracotta anthropomorphic statues, the head of another statue and fragments of a kernos ring (Petit and Kafafi 2016). On the floor of the building, two cattle skulls had been carefully positioned, looking south and east.
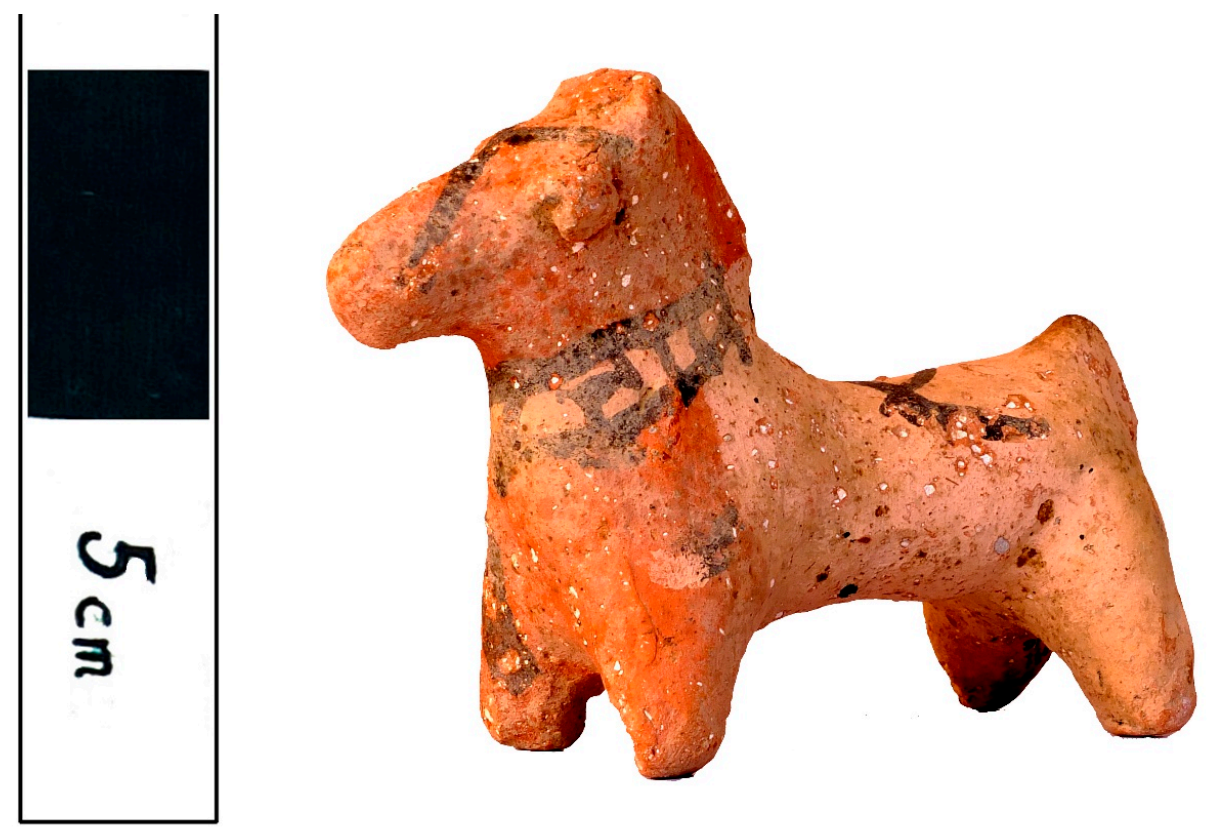

Figure 3. Horse figurine found at Tell Damiyah (Photo by Yousef al-Zu'bi. Courtesy Rijksmuseum van Oudheden Leiden and Yarmouk University, Jordan). 
The building was located amidst several small houses, of which so far one has been excavated, containing ordinary household wares, bread ovens, grinding stones and loom weights. This occupation phase dates to the late 8th-early 7th century BC. The buildings were destroyed by a fierce fire.

Based on the size of the building, the objects found in and around it, and the lack of ordinary household wares, an identification as a temple or shrine is legitimate. Further excavations may clarify whether this is an isolated building or the uppermost of a series of temples.

\subsection{Ataruz}

At Khirbat Ataruz in ancient Moab, a large temple complex has been excavated from 2000 onwards. The first phase of this building consisted of a main room with a niche with a pedestal-like installation and a platform. In the courtyards around the building a possible 'high place' and an altar were found (Ji 2012).

In the next and final phase II, the complex consisted of a multi-chambered building with at least three parallel long rooms fronting a courtyard (Figure 4$)$. The main room $(8.5 \times 11 \mathrm{~m})$ had a large unhewn stone slab standing upon a pedestal built in the niche and contained a variety of objects, among which were a large pottery bull, jars decorated with bulls heads and a fenestrated altar with two male figures. The other rooms featured a square stone-built hearth of $2 \times 2 \mathrm{~m}$ in one room and two stone-built platforms in the other. All in all, "hundreds of cultic objects" have been retrieved from the temple complex (Ji 2012, p. 210). According to the excavator, the principal deity is symbolized by the standing stone in the main sanctuary room and by the bull figurine; which deity this is remains a question mark (Ji 2012, p. 218).

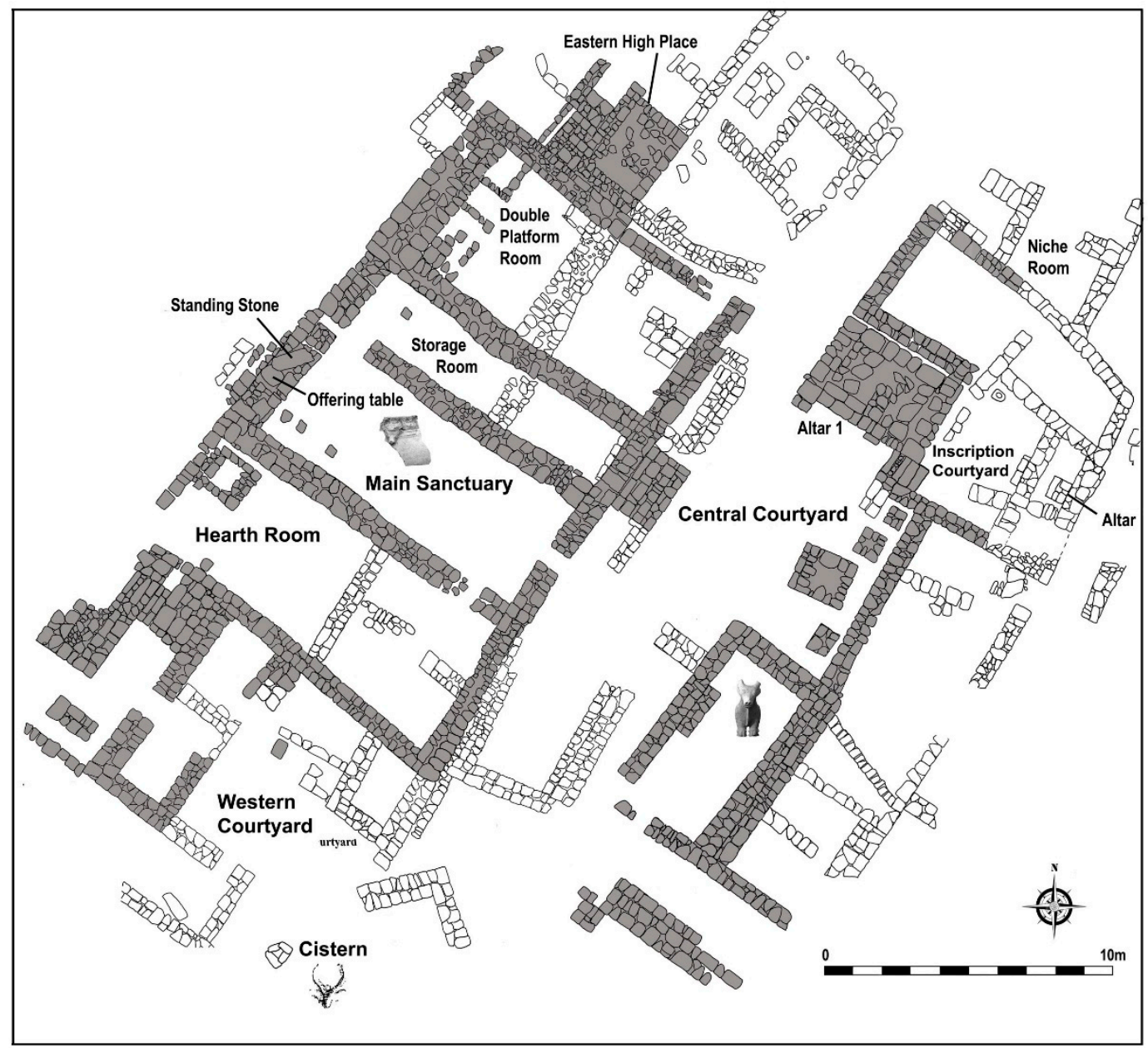

Figure 4. Plan of phase II building at Khirbat Ataruz (Courtesy Chang-Ho Ji). 
The stone pedestal of an incense altar with an inscription was recently discovered in one of the smaller courtyards. The text has not yet been published, but Rollston writes on his web blog that it is written in the Moabite language and he dates the writing 'comfortably' in the 9th century BC on paleographic grounds. $^{2}$

The excavator dates both phases to the end of Iron Age I and the beginning of Iron Age II, late 10th to early 8th centuries BC (Ji 2011, 2012). The site was destroyed by fire. Very little pottery has been published so far, which hinders a more precise dating of the complex.

After the fire that destroyed this building complex, the town was rebuilt and the eastern side of the large courtyard continued to be used for cultic activities in Iron IIB-C (7th century BC), but on a much smaller scale, according to the excavators (Ji and Bates 2014, p. 51). Not much information is as yet available on this phase III. This new town was destroyed at the end of Iron IIC.

The architecture of the building at Ataruz in phases I and II and the overwhelming number of special vessels leave no room for doubt that this is a cultic building, a large temple. It closely resembles the temple at Arad in Israel, also dating to the Iron IIB. Both have more or less the same dimensions, they have stone-built platforms, large stone altars for offering and niches. Whether the temple at Ataruz was dedicated to Jahweh or Kemosh or both is a matter of debate. Cultic activities seem to have continued in some form into the later Iron Age II (phase III).

\subsection{Mudayna Thamad}

A smaller possibly cultic building was unearthed at Khirbet al-Mudayna in the Wadi ath-Thamad, located in the norther part of ancient Moab and dating to the 7th century BC (Daviau and Steiner 2000). The structure (B149) was $5.5 \times 5.5 \mathrm{~m}$ with plastered benches on three sides (Figure 5). Two pillars connected by a bench divided the room into the main area and a small annex.

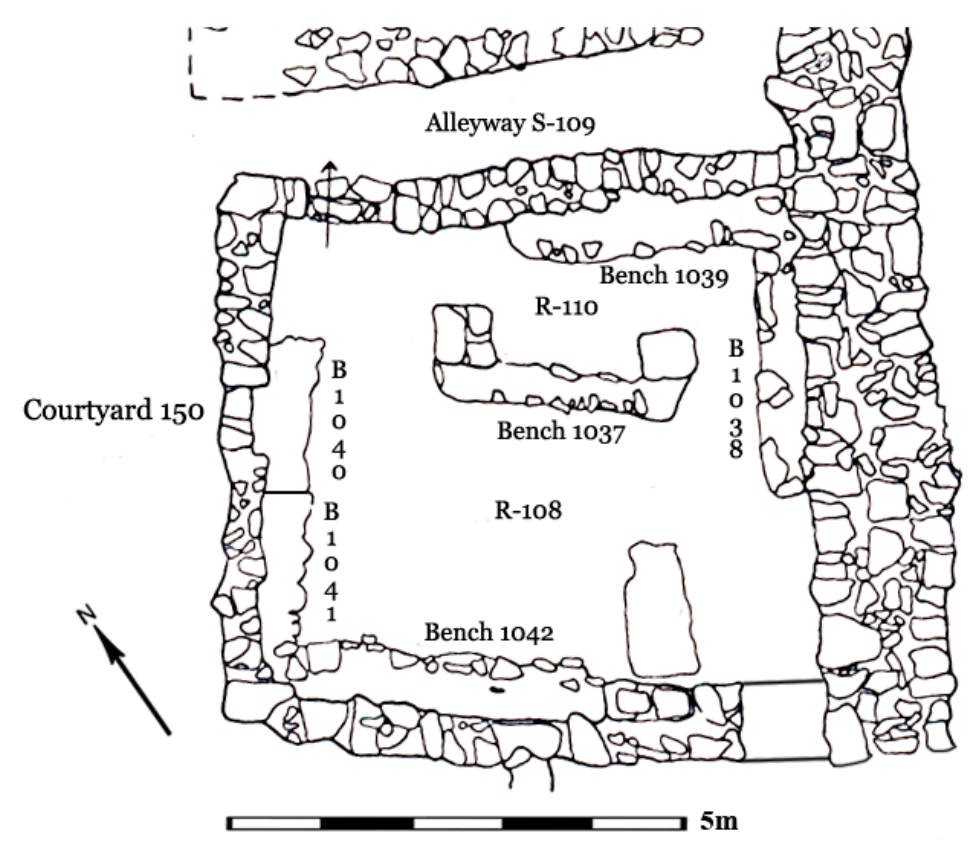

Figure 5. Plan of Building 149 at Mudayna Thamad (Courtesy Wadi ath-Thamad Project).

One libation altar and two shaft altars, all three made of stone, were found inside the building, one bearing an inscription reading "the incense altar that Elishama made for YSP, the daughter of WT" (Dion and Daviau 2000; Daviau 2002; Rainey 2002). Other finds in the shrine include five ceramic oil

2 http://www.rollstonepigraphy.com/?p=631. 
lamps, several fragmentary female figurines, two large stone pegs, two Wadjet-eye amulets, two murex shells, a spouted vessel and some beads. Some household pottery (bowls, storage jars) was also found.

It seems that most material was removed from the building when the town was attacked and it was used to forge iron arrowheads. A large pit was cut into the floor and later resealed while the building was still in use. Only a few objects were found in this pit: ceramic sherds from seven fragmentary vessels and a stone with a depression, possibly a mould for the manufacture of metal tools.

The courtyard west of the building was an open plaza behind the gate through which one entered the town. Embedded in the floor of the plaza, thousands of animal bones were excavated, mostly of sheep and goat. These remains have been tentatively interpreted as butchering waste for rituals involving the offering of meat in the shrine (Popkin 2009). However, the connection with B149 is not clear.

The town was destroyed when it was attacked around $600 \mathrm{BC}$. It is remarkable that the gate and many buildings in the town were destroyed by a heavy fire, but that the shrine remained relatively unscathed. This can be coincidental, or the attackers respected the shrine and did not set fire to it.

The identification of the building as a shrine or small temple was based on its architecture with benches, the (admittedly few) finds therein, particularly the three altars and the stone pegs, the inscription on the stone altar and the animal bones on the adjacent courtyard, possibly the remains of meat offerings in the building. To which deity the place was dedicated is unknown.

\subsection{A Gate Shrine at Mudayna Thamad?}

Outside the gate of Mudayna, a possible cultic installation was excavated, with two standing stones, 0.60 and $1.05 \mathrm{~m}$ high, the largest of which had fallen over (Figure 6). These two stones were held in place by a number of smaller chink stones carefully placed around them to act as supports. The two standing stones abutted a large $1.30 \mathrm{~m}$ long stone, placed on its side into the ground directly to the east. The excavators interpreted the upright stones as masseboth and the construction as a gate shrine, even though no cultic material was found nearby (Daviau et al. 2006, p. 252 and Figure 4).

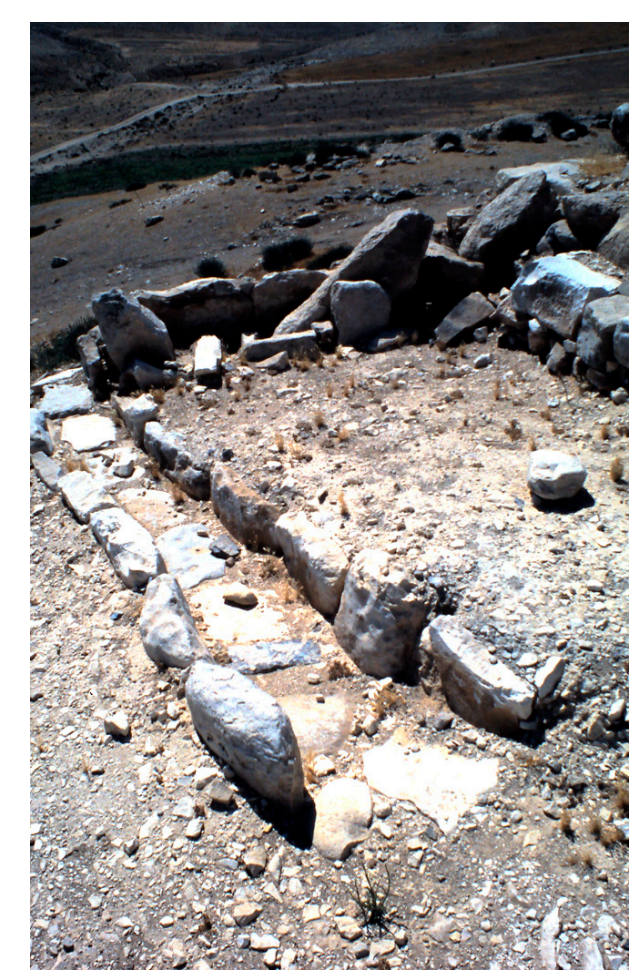

Figure 6. Photo of possible gate shrine at Mudayna Thamad (Courtesy Wadi ath-Thamad Project). 
The identification of this construction as a shrine rests on the find of the large stones only. In the absence of pottery and other special finds, the cultic nature of this site remains doubtful. ${ }^{3}$

\subsection{WT-13}

Some $3 \mathrm{~km}$ west of Mudayna Thamad, an open-air site has been excavated (site WT-13 of the Wadi ath-Thamad survey) (Dolan 2007; Daviau 2012, 2017). On a hilltop, a perimeter wall enclosed an area of c. $7 \times 14 \mathrm{~m}$. Large stones inside the wall may have served as benches (Figure 7). Inside the enclosure wall, a large collection of ceramic statuettes and figurines was found. Many statuettes hold a disc in their hands, comparable to the figurines of Horvat Qitmit in the Negev and 'Ein Hazeva in the Wadi Araba on the border with Edom. Other finds include architectural models and attached figures, miniature furniture, amulets and scarabs, miniature ceramic vessels, jewellery, marine shells, fossils and exotic geological samples. All in all, more than 500 broken objects were retrieved from this site, along with more than 25,000 pottery sherds. The pottery dates this complex firmly in the later Iron II period, 8 th and 7 th centuries BC.

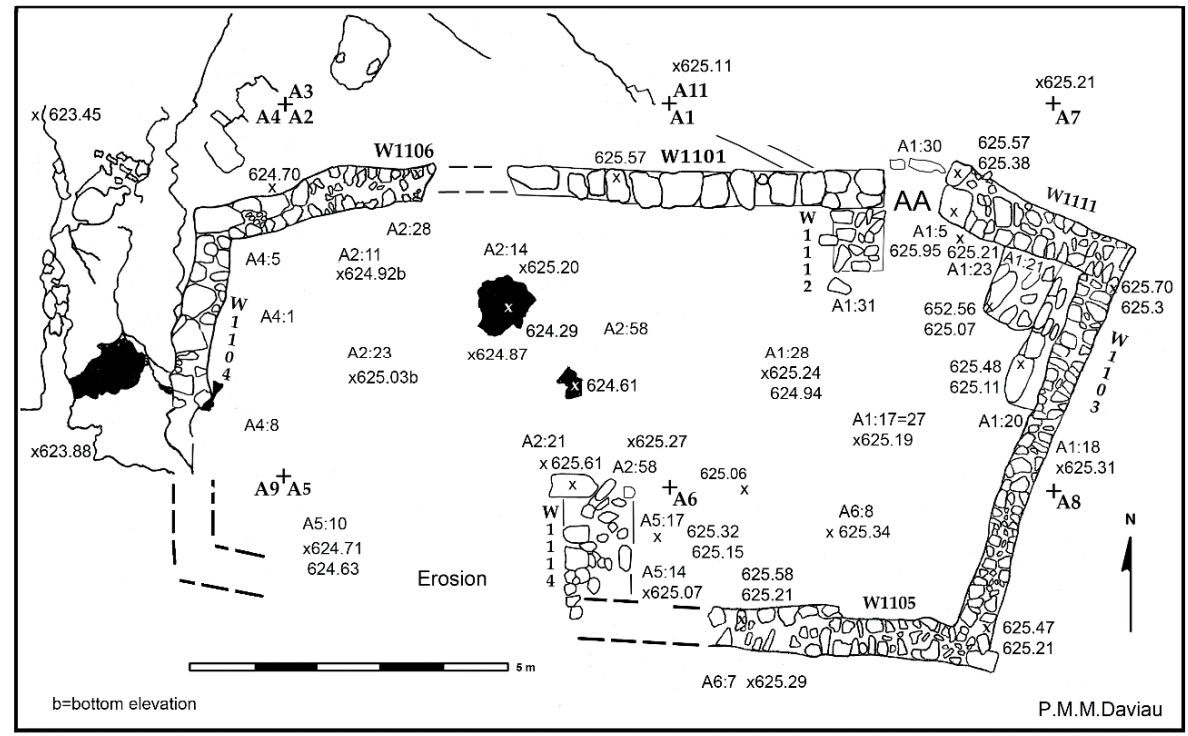

Figure 7. Plan of cultic complex at WT-13 (Courtesy of Wadi ath-Thamad Project).

An earlier occupation phase consisted of five cooking installations with ashes and a large number of animal bones, dating to the Iron I/IIA period (11th-10th centuries BC). It is unclear whether these finds constitute an earlier phase of the sanctuary or if they are the remains of household activities.

The architecture and large amount of votive objects of the later phase leave little doubt that this is an open-air cultic complex, comparable to Horvat Qitmit; the cultic nature of the earlier phase with the cooking installations is not established.

\subsection{Buseirah}

A possibly cultic building was excavated at Buseirah, which is ancient Bozrah, the main city of the Edomites in the 7th and 6th centuries BC. In area A, the acropolis, two wings of a building were excavated, consisting of rooms around inner courtyards, a staircase flanked by two circular stone bases, plastered rooms and plastered water drains. Some of the smaller rooms contained a large number of cylindrical jars and may have served as storerooms. Bennet (1983, p. 15) interpreted the complex as a temple, an interpretation followed by Reich (1992, p. 219) though no objects were found in the building

3 Another possible gate shrine in Jordan is discussed in Tyson (this volume, paragraph 4.1.4). 
to corroborate this. In the publication of the excavations, Bienkowski (2002, p. 95) very cautiously accepts the notion that the building was a temple rather than a palace or public building.

Some elements of the Buseirah building can be compared with those in other temples in the Levant, such as the long narrow plastered room, the steps flanked by stone pedestals and the storerooms with storage jars, presumably with oil for use in temple ceremonies (Bienkowski 2002, p. 95). However, none of the parallels fits neatly and the lack of cultic objects indicates that another interpretation is possible.

\section{Classification of the Iron Age Cult Sites of Transjordan}

Zevit has drafted a consistent terminology for the various kinds of cultic sites (Zevit 2001, pp. 123-24):

- Cult place: general designation for a place where cultic activities took place.

- Cult room: room designated for cultic purposes. This could be a room in a domestic or a public building, or it could be attached to such a building.

- Cult corner: part of a room or courtyard designated for cultic purposes.

- Cult cave: natural or man-made cave where cultic acts were performed.

- Cult complex: large cult place comprised of more than one structure, but one that does not contain within it any dedicated buildings.

- Cult center: a large cult place comprised of more than one structure, that does not contain a dedicated building, and for which the term 'temple' seems inappropriate.

- Temple: large single-roomed or multi-roomed structure with adjacent or internal open spaces and courts used for cultic purposes.

- Temple complex: a combination of temples or of temples and cult rooms.

- Shrine: closet-size freestanding structures that housed images or symbols of a deity.

- Cult site: general designation for any of the above or an ill-defined cult room or cult corner.

Zevit's research shows that the cult places of Ancient Israel are very varied. There were small cult rooms and corners in towns and outside the gates, temples and large temple complexes inside and outside the towns, open-air sanctuaries and cult caves. No one building is identical to another one. The same seems to apply to Transjordan—see Table 1.

Table 1. Presents the Iron Age cult places excavated in Transjordan discussed above and the rituals that might have taken place in them.

\begin{tabular}{|c|c|c|c|c|}
\hline Building & Excavated & Zevit's Typology & Location & Rituals (Adapted from Daviau 2012) \\
\hline Pella & $\begin{array}{l}\text { Building and courtyard with altar and } \\
\text { animal bones, cultic vessels } \\
\text { and objects }\end{array}$ & Temple & In town & $\begin{array}{c}\text { Presentation of (meat) offerings, use } \\
\text { of votives }\end{array}$ \\
\hline \multicolumn{5}{|l|}{ Ataruz } \\
\hline $\begin{array}{c}\text { Phases I and } \\
\text { II }\end{array}$ & Cella, other rooms, courtyards, altar & Temple & In town & $\begin{array}{l}\text { Worship by standing stones, } \\
\text { meat offerings }\end{array}$ \\
\hline Phase III & Cultic objects & Cult corner? & In town & Use of votive objects? \\
\hline Mudayna & $\begin{array}{l}\text { Small benched room, incense altars, } \\
\text { votive objects }\end{array}$ & Temple/cult room & In town & $\begin{array}{l}\text { Libations, burning of aromatics, use } \\
\text { of votive objects }\end{array}$ \\
\hline Buseirah & $?$ & Temple? & In town & Unknown \\
\hline
\end{tabular}

Iron Age cult places excavated in Jordan. 


\section{To Which Gods?}

To which deities these temples and cult sites were dedicated remains unclear. Except for Deir Alla, no inscriptions mentioning a god have been found, nor any statues that could be identified with known deities.

The Balaam inscription at Deir Alla (Section 3.1) mentions an interesting combination of gods: $\mathrm{El}$, Shagar, the Shadday gods and Ashtar. El was the supreme deity of the Canaanite pantheon, while Ashtar is probably the male counterpart of the female Ashtarte. Shagar, the acting deity in this story, is a goddess not known in the Canaanite or Phoenician pantheon. The Bible mentions 'the shagar of thy cattle and the ashtarot of thy sheep' (Deut. 7:13, 28:4, 18,51). This is usually translated as 'the fruit of thy cattle and the flocks of thy sheep'. With this translation, of shagar as 'fruit' and ashtarot as 'flocks', the translators don't seem to do justice to the original text. Apparently, Shagar and Ashtarte were goddesses guarding the fertility of the flocks, and were well known in ancient Israel. The Shadday-gods seem to represent a particular group of gods. In the Bible, El Shadday is one of the names of the god of Israel.

The temple of Ataruz (Section 3.4) may have been dedicated to the main deity of Moab, Kemosh. The excavator, however, interprets the building as a temple dedicated to the god of Israel, JHWH. No solid proof is available for either position.

\section{Conclusions}

Several cult places have been excavated in the area east of the river Jordan, from large temples to smaller shrines to open-air complexes. The architectures and inventories of these sites show a wide variety, with stone-built altars, standing stones possibly representing deities, and the deposition of votive objects in pits and on benches. Meat offerings may have been presented next to libations and the burning of aromatics. The shrines may have been locally used or may have served a wider region. Some temples were undoubtedly dedicated to the main state deities Milkom, Kemosh, and Qos, or the god of Israel, JHWH, while smaller shrines seem to be related to other gods, such as the cult room at Deir Alla where Shagar is mentioned.

Although not all cult sites have as yet been fully published, they are an important addition to the corpus of cult places known from the areas west of the river Jordan.

Funding: This research received no external funding.

Conflicts of Interest: The author declares no conflict of interest.

\section{References}

Bennet, Crystal M. 1983. Excavations at Buseirah (Biblical Bozrah). In Midian, Moab and Edom; The History and Archaeology of Late Bronze and Iron Age Jordan and North-West Arabia. Edited by John F. A. Sawyer and David J. A. Clines. Sheffield: JSOT Supplement Series, vol. 24, pp. 9-17.

Bienkowski, Piotr. 2002. Busayra Excavations by Crystal-M. Bennett, 1971-1980. Oxford: Council for British Research in the Levant/Oxford University Press.

Blake, Edward. 2005. The Material Expression of Cult, Ritual and Feasting. In The Archaeology of Mediterranean Prehistory. Edited by Edward Blake and Bernard Knapp. Oxford: Blackwell, pp. 102-29.

Boertien, Jeannette. 2008. Unravelling the threads; Textiles and Shrines in the Iron Age. In Sacred and Sweet; Studies on the Material Culture of Tell Deir 'Alla and Tell Abu Sarbut. Edited by Margreet L. Steiner and Eveline J. van der Steen. Leuven: Peeters, pp. 135-51.

Bourke, Stephen. 2004. Cult and Archaeology at Pella in Jordan: Excavating the Bronze and Iron Age Temple Precinct (1994-2001). Journal E Proceedings of the Royal Society of New South Wales 137: 1-31.

Bourke, Stephen. 2012. The Six Canaanite Temples of Tabaqat Fahil. Excavating Pella's Fortress Temple (1994-2009). In Temple Building and Temple Cult: Architecture and Cultic Paraphernalia of Temples in the Levant (2.-1. Mill. B.C.E.), Proceedings of a Conference on the Occasion of the 50th Anniversary of the Institute of Biblical Archaeology 
at the University of Tübingen, Tübingen, Germany, 28-30 May 2010. Edited by Jens Kamlah. Wiesbaden: Harrassowitz, pp. 159-202.

Coogan, M. D. 1987. Canaanite origins and lineage: reflections on the religion of ancient Israel. In Ancient Israelite Religion: Essays in Honor of Frank Moore Cross. Edited by P. D. Miller, P. D. Hanson and S. Dean. McBride: Fortress Press, pp. 115-24.

Daviau, P. M. Michèle. 2002. Stone altars large and small: The Iron Age altars from Hirbet el-Mudeyine (Jordan). In Sacred Time, Sacred Space. Archaeology and Religion of Israel. Edited by Barry M. Gittlen. Winona Lakes: Eisenbrauns, pp. 125-49.

Daviau, P. M. Michèle. 2012. Diversity in the Cultic Setting. Temples and Shrines in Central Jordan and the Negev. In Temple Building and Temple Cult: Architecture and Cultic Paraphernalia of Temples in the Levant (2.-1. Mill. B.C.E.), Proceedings of a Conference on the Occasion of the 50th Anniversary of the Institute of Biblical Archaeology at the University of Tübingen, Tübingen, Germany, 28-30 May 2010. Edited by Jens Kamlah. Wiesbaden: Harrassowitz, pp. 435-58.

Daviau, P. M. Michèle. 2017. A Wayside Shrine in Ancient Moab; Excavations in Wadi ath-Thamad. Wadi ath-Thamad Project I. Leiden: Brill.

Daviau, P. M. Michèle, and Margreet L. Steiner. 2000. A Moabite Sanctuary at Khirbat al-Mudayna. Bulletin of the American School of Oriental Research 320: 1-20. [CrossRef]

Daviau, P. M. Michèle, Robert Chadwick, Margreet L. Steiner, Michael Weigl, Annlee Dolan, Zoe McQuinn, Noor Mulder-Hijmans, Margareth Judd, and Jonathan Ferguson. 2006. Excavation and Survey at Khirbat Al-Mudayna and its Surroundings; Preliminary Report of the 2001, 2004 and 2005 Seasons. Annual of the Department of Antiquities in Jordan 50: 249-83.

Dion, Paul, and P. M. Michèle Daviau. 2000. An Inscribed Incense Altar of Iron Age II at Hirbet el-Mudeyine (Jordan). Zeitschrift des Deutschen Palastina-Vereins 116: 1-14.

Dolan, Annlee. 2007. Wadi ath-Thamad Site WT-13. A Hermeneutical Approach to Moabite Religion. Ph.D. Dissertation, University of Toronto, Toronto, ON, Canada.

Elkowicz, Dominik. 2014. Der ammonitische Mondtempel von Ruğm el-Kursi und die Tempel des "Syrischen Tempeltypus". Biblische Notizen 160: 51-57.

Franken, Hendricus. 2008. Deir Alla and its Religion. In Sacred and Sweet; Studies on the Material Culture of Tell Deir 'Alla and Tell Abu Sarbut. Edited by Margreet L. Steiner and Eveline J. van der Steen. Leuven: Peeters, pp. $25-52$.

Hoftijzer, Jacob, and Gerrit van der Kooij. 1976. Aramaic Texts from Deir Alla. Leiden: Brill.

Hoftijzer, Jacob, and Gerrit van der Kooij, eds. 1991. The Balaam Text from Deir 'Alla Re-Evaluated, Proceedings of the Symposium, Leiden, The Netherlands, 21-24 August 1989. Leiden: Brill.

Hübner, Ulrich. 2009. Der Mondtempel auf Ruğm al-Kursī in der Ammonitis. In Israel zwischen den Mächten. Edited by Michael Pietsch and Friedhelm Hartenstein. Münster: Ugarit-Verlag, pp. 145-53.

Ji, Chang. 2011. Khirbat 'Ataruz: An interim overview of the 10 years of archaeological architectural findings. Annual of the Department of Antiquities of Jordan 55: 561-79.

Ji, Chang. 2012. The Early Iron Age II Temple at Hirbet 'Atarus and Its Architecture and Selected Cultic Objects. In Temple Building and Temple Cult: Architecture and Cultic Paraphernalia of Temples in the Levant (2.-1. Mill. B.C.E.), Proceedings of a Conference on the Occasion of the 50th Anniversary of the Institute of Biblical Archaeology at the University of Tübingen, Tübingen, Germany, 28-30 May 2010. Edited by Jens Kamlah. Wiesbaden: Harrassowitz, pp. 203-21.

Ji, Chang, and Robert Bates. 2014. Khirbat Ataruz 2011-2012: A Preliminary Report. Andrews University Seminary Studies 54: 47-91.

Kohlmeyer, Kay. 2012. Der Tempel des Wettergottes von Aleppo. Baugeschichte und Bautyp, räumliche Bezüge, Inventar und bildliche Ausstattung. In Temple Building and Temple Cult: Architecture and Cultic Paraphernalia of Temples in the Levant (2.-1. Mill. B.C.E.), Proceedings of a Conference on the Occasion of the 50th Anniversary of the Institute of Biblical Archaeology at the University of Tübingen, Tübingen, Germany, 28-30 May 2010. Edited by Jens Kamlah. Wiesbaden: Harrassowitz, pp. 55-78. 
Novak, Mirko. 2012. The Temple of Ain Dara in the Context of Imperial and Neo-Hittite Architecture and Art. In Temple Building and Temple Cult: Architecture and Cultic Paraphernalia of Temples in the Levant (2.-1. Mill. B.C.E.), Proceedings of a Conference on the Occasion of the 50th Anniversary of the Institute of Biblical Archaeology at the University of Tübingen, Tübingen, Germany, 28-30 May 2010. Edited by Jens Kamlah. Wiesbaden: Harrassowitz, pp. 41-54.

Petit, Lucas, and Zeidan Kafafi. 2016. Beyond the River Jordan; A Late Iron Age Sanctuary at Tell Damiyah. Near Eastern Archaeology 79: 18-26. [CrossRef]

Popkin, Peter. 2009. The Society and Economy of Iron Age Transjordan: A Contextual Zooarchaeological Analysis. Ph.D. Thesis, University College London, London, UK.

Rainey, Anson F. 2002. The New Inscription from Khirbet el-Mudeiyineh. Israel Exploration Journal 52: 81-86.

Reich, Ronny. 1992. Palaces and Residences in the Iron Age. In The Architecture of Ancient Israel from the Prehistoric to the Persian Periods; in Memory of Immanuel (Munya) Dunayevsky. Edited by Aharon Kempinksi, Ronny Reich and Hannah Katzenstein. Jerusalem: Israel Exploration Society, pp. 202-22.

Renfrew, Colin. 1985. Archaeology of Cult. The Sanctuary at Phylakopi. London: British School of Archaeology at Athens, supplementary vol. 18.

Tyson, Craig W. 2014. The Ammonites; Elites, Empires, and Sociopolitical Change (1000-500 BCE). London and New York: Bloomsbury T\&T Clark.

Van der Kooij, Gerrit. 2002. Use of Space in Settlements, An Exercise upon Deir Alla-IX. In Moving Matters. Ethnoarchaeology in the Near East, Proceedings of the International Seminar, Cairo, Egypt, 7-10 December 1998. Edited by Willeke Wendrich and Gerrit van der Kooij. Leiden: Nino, pp. 63-73.

Wenning, Robert, and Erich Zenger. 1991. Heiligtum ohne Stadt-Stadt ohne Heiligtum? Anmerkungen zum archäologischen Befund des Tell Der 'Alla. Zeitschrift für Althebraistik 4: 171-93.

Zevit, Ziony. 2001. The Religions of Ancient Israel; A Synthesis of Parallactic Approaches. London: Continuum.

(C) 2019 by the author. Licensee MDPI, Basel, Switzerland. This article is an open access article distributed under the terms and conditions of the Creative Commons Attribution (CC BY) license (http:/ / creativecommons.org/licenses/by/4.0/). 